\title{
Think Outside My Box: Staging Respectability and Responsibility in Ireland's Repeal the 8th Referendum
}

\author{
Miriam Haughton ${ }^{1 *}$, Sarah Hoover ${ }^{2}$, Ciara L. Murphy ${ }^{1}$
}

Published: March 1, 2022

\begin{abstract}
This article argues that the targeting of certain narratives of womanhood, those deemed 'respectable' and 'responsible', operated as a key performative and affective strategy during the Irish 2018 Referendum on the 8th Amendment of the Irish Constitution. When the Referendum to 'repeal the 8th' amendment was announced, both pro-choice and pro-life campaigns affiliated themselves with idealised imagery, narratives and performative strategies that focused on outdated patriarchal heterosexual constructions of 'good' women, i.e., respectable and responsible women, with the intention of convincing middle-ground voters. Pro-life and pro-choice campaigns in Ireland are deeply oppositional; that both sides identify the performativity of respectability and responsibility as the most influential narrative to convince the electorate signals that the conception of embodied womanhood and the traditional heterosexual family remains inextricably linked with idealised nationhood, entrenched with ideological, affective, political, cultural, and personal power. 'Think Outside My Box' is a call to cut ties that intersect with the foundational myth of modern Irish nationhood, and, female embodiment and representation in the twenty-first century.
\end{abstract}

Keywords: gender performativity, Irish performance and politics, postcolonial narratives, affect and shame, emigration and mobility

Infanticide is rising. Five Irish babies have been found dead on beaches or rubbish tips in various parts of the country this year, 2000. Hospitals report a shocking increase in the number of children admitted suffering from physical abuse within two-partner families. Single parents remain a severely disadvantaged socio-economic grouping, with single mothers prone to depression at twice the rate of mothers living with their life partner. The evidence implies widespread desperation (Ruane, 2000: 6-7).

\section{INTRODUCTION: THE RIGHT TO LIFE, THE RIGHT TO LIVE}

The Ireland that Ruane (2010) depicts is a grim place to live. Indeed, there has been a heavy price paid for upholding a deeply conservative and stylised performance of respectability and responsibility in Ireland, inextricably linked to church and state control of female bodily autonomy. This article argues that the targeting of certain narratives of womanhood, those deemed 'respectable' and 'responsible', operated as a key performative and affective strategy during the Irish 2018 Referendum on the 8th Amendment of the Irish Constitution relating to the legalisation of abortion services. As noted in the opening to this special issue, the 8th Amendment was inserted into Article 40.3.3 by referendum in 1983, placing the right to life of the unborn foetus as equal to that of the mother. These laws and subsequent restrictions resulted in the violation of human rights according to the Irish Council for Civil Liberties, including the right to life, to be free from torture, discrimination and arbitrary detention, the right to healthcare, information and dignity in healthcare, privacy, and bodily integrity (What is the Eighth Amendment' ICCL.ie). Thus, Irish people and narratives of nationhood have been subject to stringent policing, censorship and divisive rule for decades, creating an embittered context for any discourse concerning abortion or female bodily autonomy. Consequently, when the Referendum to 'repeal the 8th' amendment was announced, both pro-choice and anti-abortion campaigns affiliated themselves with idealised imagery, narratives and

${ }^{1}$ National University of Ireland, Galway, IRELAND

${ }^{2}$ University College Cork, IRELAND

*Corresponding Author: miriam.haughton@nuigalway.ie 
performative strategies that focused on outdated patriarchal heterosexual constructions of 'good' women, i.e., respectable and responsible women, with the intention of convincing middle-ground voters. This strategy was employed by the anti-abortion campaign groups Save the 8th (https://www.save8.ie/) and Love Both (https://loveboth.ie/) and also, the pro-choice group Together for Yes (https://www.togetherforyes.ie/).

Anti-abortion and pro-choice abortion campaigns in Ireland are deeply oppositional and contentious; that both sides identify the performativity of respectability and responsibility as the most influential narrative to convince the electorate of voting for/against abortion is deeply telling. It signals that prevailing ideas of womanhood, motherhood, and the heterosexual family in the twenty-first century remain informed by, and thus respond to, a stylised performativity of idealised nationhood as a patriarchal construct that is affective materially, ideologically, politically, and personally (Connolly, 2015; Ferriter, 2010; Fischer, 2017, 2019; Hill, 2019; Sihra, 2007). The images used in Together for Yes campaign posters, graffiti, online memes, merchandise, public debates and interviews often relied on or represented the testimony of individual women who were largely middle class, heterosexual, married, Anglophone and white. Chakravarty et al. (2020: 174) extensively analyse the failures of intersectional praxis in the 2018 referendum campaign identifying practices of:

(...) othering and silencing sections of the population in favour of demands seen to be more palatable to 'middle Ireland' in order to ensure the success of the referendum.

These married, middle-class, and white heterosexual women were situated as representative of respectable society throughout Ireland and therefore deserving of 'empathy' and 'trust' by the electorate (Begas, 2016). Conversely, the 'No' campaign (consisting of Save the 8th and Love Both groups) placed idealised motherhood to the forefront of their imagery and discourse, demonstrating how 'respectable' Irish women (i.e. mothers) do not have abortions. In both cases, the reduction of complex social and personal experience to problematic depictions of good vs bad heterosexual women and the deployment of these images signals patriarchal, capitalist, and discriminatory politics concerning respectability and responsibility. This article contends that these campaign strategies are directly at odds with the generations of feminist activists who operated networks of resistance, support and research internationally for Irish women's bodily autonomy.

This representational politics is not specific to Ireland nor to Irish debates on abortion. Foregrounding white heterosexual middle-class women as representative of any issue pertaining to womanhood and autonomy has been critiqued throughout the rise of second wave feminism and beyond (Archer Mann and Huffman, 2005; Rosenfelt et al., 1987). Black, lesbian and working-class voices were marginalised as western feminist campaigns identified strategies that were perceived as more effective for winning wider national debates in opposition to the prevailing systems of power dominated by patriarchal and conservative interests (Ahmed, 2017; Carbin and Edenheim, 2013; Chakravarty et al., 2020). However, the scope of this article will remain attuned to the cultural politics pertaining to the performance of respectability and responsibility in an Irish context, centralising the performativity and affect of shame as a political tool. To achieve this, this article offers three strands for analysis. Firstly, it will consider how respectability and responsibility operate as political tools inextricably linked with the politics and affect of shame as theorised by Ahmed (2004, 2005, 2010, 2017), Fischer (2016, 2017, 2019, 2020), Probyn (2009), Sedgwick (2003), and Tomkins (1995). Secondly, it will situate the fundamental role played by activists, primarily from 1980 to 2018, who risked personal welfare, professional opportunity, social and community inclusion, and economic hardship to support thousands of women in difficult circumstances ${ }^{1}$. Finally, it will analyse the social media performance of travel into Ireland from abroad during the referendum as a reversal, physically and affectively, of Irish women's travel outward in search of reproductive rights. This article is in conversation with, and indebted to, scholarship that acknowledges the deep histories of activism that resists the silencing processes engendered by shame and finds a way to communicate, even when speaking is unsafe or unheard.

'Think Outside My Box' critiques the ongoing impact of foundational myths of modern Irish nationhood and indeed nationhood as a master-narrative pertaining to female embodiment, autonomy, and representation in the twenty-first century. Ireland — as concept, image, and ideology of nation-emerged as a burden placed at women's wombs over a century ago. Women are supposed to know their place as keepers of this flame but not active agents in the very processes of national collective meaning-making or indeed, personal autonomy. Women's bodies represent a deeply patriarchal nexus of nationhood, law, and religious doctrine threaded together via postcolonial anxieties and needs. Ruane (2000) pinpoints the stakes at play in Ireland's respectability-responsibility dyad in 2000, well over a decade before the most recent tipping points in this long journey emerged. These tipping points include the tragic death of Savita Halappanavar in 2014 due to her being refused an abortion by University Hospital Galway

\footnotetext{
${ }^{1}$ Pro-choice abortion activism and support networks emerged before the 1980s. However, there is a limit to what we can achieve within the scope of one article, so we draw from particular examples that occur during this period as it coincides with the introduction of the Eighth Amendment.
} 
Feminist Encounters: A Journal of Critical Studies in Culture and Politics, 6(1), 11

(Specia, 2018), and the establishment of the Constitutional Convention (https://www.constitutionalconvention.ie/) in 2012. Ruane (2000: 6) details that:

Irish society needs women's silence to keep its good opinion of itself. [...] the story of Irish women is usually authored by someone else, with few women daring to speak for themselves, to become visible. But just as years of concealment about the abuse of children in state institutions were finally ruptured when its reality became untenable, years of denying the reality of abortion is starting to tell unbearably on other aspects of Irish life.

Thus, the narrative of Irish values negelecting gender equality for women has existed for almost a century. In this narrative, performative and affective relations of respectability and responsibility are deeply tied up with histories of shame for women and family, including the punitive cruelties of institutionalisation and social disgrace that remain unresolved politically and historically (Haughton et al., 2021). The importance of maintaining and defining respectability in Ireland led to a culture of shame, secrecy, and silence throughout the twentieth century, particularly around women's bodies. However, narratives are subject to context, informed by and informing the social, political, and cultural conditions in which they circulate. Recent decades have witnessed seismic shifts to social attitudes and cultural practices, including the pivotal role education has played in creating a society wherein questions can be asked, experiences can be shared, and new stories of person and place, gender and nation, can emerge. But first, this article must attend to this dysfunctional triadic relationship across respectability, responsibility and shame that pervades the affective conditions of the Repeal the 8th Referendum.

\section{"WHERE DID THE SHAME COME FROM?"}

In 1916 Dr. Thomas Gilmartin, the former Archbishop of Tuam, stated that ' $\mathrm{t}$ ] he future of the country is bound up with the dignity and the purity of the women of Ireland' (Hogan, 2019: 45). A century later, Taoiseach (Irish Prime Minister) Enda Kenny would address the hypocrisy of Irish society following the discovery of the remains of hundreds of children buried in an underground septic tank at the Tuam Mother and Baby Institution (see Tuam Oral History Project), referring to what he termed Irish people's 'perverse, morbid relationship with what you call respectability' (Hogan, 2019: 46). Over the course of one hundred years, the veil of morality, respectability, and the authority of the Roman Catholic Church (RCC) in Ireland fell ${ }^{3}$. However, in 2018 during the campaign to repeal or retain the 8th Amendment of the Irish Constitution, the narrative of both campaigns relied heavily on representations of respectability and responsibility.

Indeed, what does respectability mean? It suggests the absence of stigma, the freedom from shame, the warmth of assured collectivity via community: present, explicit, visible, and reinforced iteratively. Where respectability is considered absent, the space for shame opens up, pervading both personal and public spaces. As Fischer (2020: 998) theorises:

Shame-a negative emotion that usually involves hiding a moral failure- has long cut across public and private spheres to guarantee, through the excising of shameful gendered others and the strict regulation of women's bodies and social roles, a national identity centered on gendered superior purity and virtue. The most intimate parts of women's lives were thus structured by an emotion that traversed public and private spheres to ensure the public governance of women based on their private transgressions.

Fischer (2019: 33) identifies the pivotal role postcolonialism has played in modern nation-building that 'relied on shame and the construction of the Irish nation as a particular, gendered place,' which enacted 'gendered displacement' via its policies on Irish women's right to travel for abortion, but not access those services domestically. Although the structures and belief systems that contributed to the existence of Ireland's religious institutions pre-dates the independent Irish state, post-independence the Irish state relied on the financial, social, and moral support, primarily of the Roman Catholic Church (RCC) in order to maintain its schools, hospitals, and social institutions. Essentially, the new Irish state was built on Catholic resources and doctrine, and as a result many of its emerging social and political structures were influenced by religious dogma and an outward collective social performance of respectability. For almost a century, the RCC was the gatekeeper and arbiter of what constitutes respectability in Ireland and the outward performance of this respectability often came at a large cost

\footnotetext{
${ }^{2}$ Hogan (2019: 10).

${ }^{3}$ In the 1990s the culture of silence that pervaded Church-run institutions and structures was starting to wane. The emergence of the Clerical Child Sex Abuse scandal in 1995 via the arrest of Fr. Brendan Smyth as well as the public reaction to several public scandals that emerged as a result of the Church's interference in society such as Ann Lovett's death in Granard, Co. Longford and the Kerry Babies Scandal in 1984 contributed to this dynamic.
}

(C) 2022 by Author/s 
to those for whom access to many forms of health care is not yet equitable: women, children, people living rurally, Traveller/Mincéir, disabled, income-restricted, and minority-ethnic people (Carnegie and Roth, 2019). Pregnancy and the conditions of pregnancy in twentieth century Ireland are topics that challenge respectability. Even within the marriage unit, Catholic teachings asserted that sex was for reproductive purposes only and not for pleasure. Virginity was godly; sexual activity was sinful. Following a birth, a married woman had to be 'churched;' some argue this religious ritual is in thanks for the gift of a newborn, others tell it is to make women feel 'unclean' (Hogan, 2019; Opie and Tatem, 1996). To be a woman or a child pregnant outside of marriage, no matter the circumstance, was a major 'scandal in the parish,' which had to be dealt with. This led to a culture of hiding crisis pregnancies by women and their families, who were often pressured to send them into the many Church and staterun institutions for unmarried mothers or 'fallen women.' (Haughton et al., 2021; Smith, 2008; Tuam Oral History Project, NUI Galway, 2019-2023). Following the introduction of the 8th Amendment in 1983, the practice of Irish women travelling to Britain for abortion services and to escape this nexus of Irish-church state control became further cemented (Murray and Grimes, 2021; Rossiter, 2009)4.

Even when the sense of shame, as encapsulated in disapproval, has been rejected by those who have sought abortion, the weight of judgement from others operates to silence and separate them and must be overcome with effort, as Flynn's (2015) article about her abortion demonstrates:

I wasn't ashamed. I made the most responsible choice I could have made at that time and in those circumstances. But I was shamed into silence. (...) I became a criminal. Guilty. Shameful. A killer.

Tomkins' (1962) approach to shame emphasises the estrangement of those who feel the affect, which he places in the polarity shame-interest. He describes shame as a 'barrier to further exploration which partially reduces interest' and a 'high toxicity' affect, arousing anxiety and distress, as well as isolating those who experience it in 'an interruption and a further impediment to communication' (Tomkins, 1962, I and II: 123; 1995: 133, 137). Shame moves one to lower the eyes, to sever contact, to turn away from the view of others:

One wishes to look at or commune with another person but suddenly cannot because he is strange, or one expected him to be familiar but he suddenly appears unfamiliar (Tomkins, 1995: 135).

Sedgwick (2003: 36) identifies the 'disruptive moment' of shame as it separates us, interrupting 'a circuit of identityconstituting identificatory communication' between those with whom we seek to identify and ourselves at a deep level. Though both approach shame with an emphasis on response to strangeness rather than disapproval, the distancing effect from one's identity as a member of a family or community results in the same isolation and separation.

This shame became challenged by changes in the late twentieth century, of which feminism was a leading discourse and methodology for action. The Irish Women's Movement, which gained momentum during the 1970s, relied on second-wave feminist methodologies, such as direct action and consciousness-raising, as a means to campaign for and promote equality for Irish women (Connolly, 2003; Connolly and O'Toole, 2005). These activities occurred at a moment in time when the ties between Church and state were waning and there was an opportunity to re-cast Irish women as equal citizens in the workplace, at home, and in terms of bodily autonomy. Unlike the second-wave feminist movements in Britain and the United States, second-wave feminism across the island of Ireland evolved from and through working-class women's groups, focusing on a culture of resistance and support for vulnerable and marginalised women across the island of Ireland regarding a variety of domestic, workplace, sexual and reproductive issues. The Irish Women's Movement challenged the gendered state structures that insist that women in Ireland are inherently considered to belong to the domestic space. Ireland's current constitution (ratified in 1937) reflects this dynamic in Article 41.2 where women are established as having their place in the home or domestic sphere ${ }^{5}$. The article also uses the terms woman and mother interchangeably, linking them in this domestic space with children. The rise of an active, and broadly successful, women's movement in the 1970s led significant conservative backlash in the 1980s resulting in the introduction of the 8th Amendment of the Irish Constitution.

Turning towards affect to consider the images that were so very present in the public space raises awareness of the power of embodied subjectivity in the debate around inclusion and exclusion in decision-making about reproductive choice. As Pedwell and Whitehead argue, feminist affective analysis is concerned with 'how power

\footnotetext{
${ }^{4}$ This article refers to Britain rather than the United Kingdom. Unlike Britain, Northern Ireland's restrictions on abortion access were retained until October 2019. Women seeking abortion access outside of Ireland had to travel to Britain to receive healthcare.

${ }^{5}$ Article 41.2.: 'In particular, the State recognises that by her life within the home, woman gives to the State a support without which the common good cannot be achieved. The State shall, therefore, endeavour to ensure that mothers shall not be obliged by economic necessity to engage in labour to the neglect of their duties in the home' (The Irish Statute Book).
} 
circulates through feeling and how politically salient ways of being and knowing are produced through affective relations and discourses' (Pedwell and Whitehead, 2012: 116). Affective resonances move bodies; they cause action, influencing and influenced by the 'conditions under which bodies are enculturated, psychologised, given identity, historical location, and agency' (Grosz, 2004: 2). Affect 'sticks' to bodies, as Ahmed (2004: 29) asserts, and 'sustains or preserves the connection between ideas, values and objects' with women's reproductive bodies being objects to which the affective resonances of shame and stigma stick. Affective resonances are woven into the legal, social, and religious narratives that insist Irish women act respectably and responsibly, maintaining the secrecy surrounding acts that contradict this.

Ahmed (2005) contends that the appearance of the respectable, responsible woman represents the nation's idea of itself. Therefore, to belong to the nation, such individual differences as the reason to have an abortion must be hidden. The woman who had a 'bad' abortion:

(...) must give up her concrete difference in the interests of the national ideal, in which freedom takes the form of a particular kind of body (a particularity that is given value insofar as it is represented as abstract-able or detach-able from particular bodies (Ahmed, 2005: 98).

In short, the public sphere in Ireland in 2018 still demarcated the limits for women's agency. The experience and strategies of the campaign - the posters, the social media content, the soundbites, the testimonies, the medical expertise, the debates, the performativity of it all-reminds society that while the rules regarding female autonomy may have changed they have not disappeared. The space of women's embodied liberty remains framed by the borders of historical, patriarchal, religious, conservative hegemony who may never experience a crisis pregnancy nor the associated social gaze of contempt. Thus, the campaigning by both pro- and anti-abortion activists performed another function alongside their overt political aims. They reasserted which narratives can be welcomed, supported, tolerated, and indeed, which narratives should know their place; out of the collective community public space, ethically suspect and therefore non-starters as representative of respectable female experience and respectable nationhood. It is this discomforting space between the socially-acceptable abortions and the remaining contexts of abortion that sheds harsh light on how and why the role of 'respectability' and 'responsibility' still informs the discourse and practice of community-building in contemporary Ireland. This article therefore must acknowledge the decades of activism that dealt with crisis pregnancies, beginning its analysis before the Repeal moment and concluding with the rejuvenating reversal of emigration patterns to cause political change.

\section{'TRUST WOMEN': THE BATTLE FOR MIDDLE IRELAND}

This article acknowledges the significant work that occurred as part of the pro-choice Referendum campaign to prepare the ground for the eventual confident victory, much of which is explored elsewhere in this edition ${ }^{6}$. Part of this campaign required creating conditions for change. Creating these conditions can include major knowledge-based efforts, such as easy access to empirical data and engagement from relevant expertise, as well as harnessing methods of persuasion, such as being able to identify and empathise with another's pain. Irish Labour Party Senator and long-time pro-choice advocate Ivana Bacik reflects on these complexities. Bacik (in Bacik and Haughton, 2021) maintains:

It's not as clear cut as the referendum marks the shift in public mood. Referendum campaigns themselves change people's views. Most people don't have a clear view in advance. There's the $20 \%$ rule- $20 \%$ will never vote for you, and vice versa, but there's an enormous majority in the middle—and it's those people that will be affected by the campaign.

To sway that middle-ground, campaigns centralise stories that the perceived majority can identify with. In the case of the Referendum to Repeal the 8th, Terminations for Medical Reasons (TFMR), a collective of parents who experienced diagnoses of fatal foetal conditions, became one constituency of highly-charged narratives that the pro-choice campaign identified as convincing to the wider populace. These accounts of tragic diagnoses highlight, with incredible dignity and generosity, the inhumane and cruel treatment those women and couples experienced as a result of Ireland's abortion laws. However, there are women and couples who did not feel welcome to share their experiences during this campaign. Some felt nervous that they would be seen as a 'bad' abortion, i.e., where the foetus is physically viable, but the pregnancy is not viable for the woman. This is demonstrated by the centrality of an argument in the No campaign that repealing the 8th would allow 'abortion on demand' and agreement by some in their opposition that they also found full agency too radical to support. As Browne and Nash (2020: 62) state:

${ }^{6}$ All of this article's authors were publicly pro-choice during the Repeal campaign.

(C) 2022 by Author/s 
'On demand' implies that abortion is an unneccesary, consumptive choice. It is on demand, as desired, without checks or regulation, free and accessible to all. Behind the 'on demand', good/bad abortion binary is the invisible specter of the 'bad' woman (and, in heteroactivist rhetoric, it is not a pregnant person; it is a heterosexual woman) who uses abortion as contraception. This woman has hetero sex and is not 'careful' or not careful enough.

As a counterexample to abortion 'on demand', the Yes campaign repeatedly raised the 'good' abortion as an act only allowable due to tragic circumstances. Cullen and Korolczuk's (2019) cross-cultural study of the referendum demonstrates this deliberate rhetorical strategy operating to invoke tragedy and de-emphasise radical or intersectional frameworks in order to destigmatise abortion, and Carnegie and Roth's (2019) analysis similarly notes the campaign's focus on 'hard cases'. This evident anxiety concerning which women feel welcome and supported by established political organisations to speak out regarding their embodied experiences in public space is telling of the deep pressure that remains inscribed on those public spaces. Those public spaces, thus, are affective and performative in social, personal, and material ways.

The performance of respectability is echoed throughout the 2018 campaign to repeal or retain the 8th Amendment in order to sway the enormous 'majority in the middle.' Extremes were only permitted in certain circumstances and the Together for Yes campaign focused on the 'hard cases'; those mainly married, heterosexual, white Irish women whose pregnancies would not be viable outside of the womb. MERJ (Migrants and Ethnic Minorities for Reproductive Justice) criticised the exclusion of migrant voices throughout the campaign. Writing on the issue for Village, Candon (2020) condemns the 'homogenised, top down 'Together for Yes' campaign' as one focused on 'moralised debates in mainstream media led by politicians and public figures in place of grassroots campaigners'. Candon's (2020) criticisms reflect growing discomfort in activist circles that the mainstream campaign was at odds with what activists had been focusing on for decades.

The anti-abortion campaign consistently presented concerns that women are not responsible enough to make decisions regarding their personal bodily autonomy and pregnancies, as demonstrated elsewhere in this article and this issue in evaluating campaign ephemera demanding resistance to 'on demand' abortions. Similarly, the 'love both' message plastered on stickers and posters throughout the campaign represents a love that entails protecting women from themselves and their own choices. This redeployment of an argument equalising the personhood of a foetus and an adult nevertheless positions the adult woman as both vulnerable and irresponsible, liable to make choices dangerous to herself and to the propagation of Irish values. The movement towards liberalising Ireland's restrictive abortion law saw significant pushback from the Catholic Church in Ireland and its adherents. The language and imagery surrounding this was extreme, designed to incite hysteria and anger. From the tragic death of Savita Halappanavar in 2014 and throughout the Repeal campaign, the narrative from the anti-abortion community was consistent: women are not responsible and cannot be trusted. Former Master of Ireland's National Maternity Hospital and consultant obstetrician Boylan (2019: 106) recalls that:

Some anti-abortion members of the Oireachtas continued to drive a narrative that women would manipulate the provision for termination where it was allowed in cases of a risk of suicide and that this would result in a huge increase in terminations. The implication was that women could not be trusted.

Thus, the social pressure generated by pro-choice campaigns included the focus on foregrounding women deemed 'trustworthy': such problematic language is deeply resonant, if not interchangeable with, 'respectable' and 'responsible' in the Irish cultural context.

Smyth (1995: 35) acknowledges that '[v]irtually all of [Ireland's recent] crises and controversies have crystallized, and been concretized, around an individual case'. Similarly, historian Ferriter (2010: 544) notes that:

By the early twenty-first century, the boundaries of what is and is not acceptable to publish in the realm of Irish sexuality have changed beyond recognition. There is a high premium placed on the value of personal testimony, a dominance of the memoir as a literary genre, a confessional culture and the personalisation of debate, which have all combined to expose the myth of exceptional Irish purity.

Thus, performativity of selfhood, and the empathetic affective energy this fertilises, stages the conditions for a heightened and persuasive campaign. The road to repealing the 8th Amendment was influenced by this dynamic and Ireland's restrictive abortion regime was placed to the forefront of public consciousness via the tragic death of Savita Hallappanavar. Throughout the state's recent history, women (and children's) personal stories have been the catalysts for major changes in Irish society ${ }^{7}$. The price for overturning a culture of silence and shame seems to

\footnotetext{
${ }^{7}$ Such as: Ann Lovett, Joanne Hayes, the X Case, Savita Halappanavar, Vicky Phelan through the CervicalCheck scandal which emerged in Ireland April 2018, and the hundreds of anonymous contributors to the Ryan Report and McAleese Reports.
} 
be the exposure of embedded trauma in the public sphere. Throughout the campaign, a number of high-profile women came forward and shared their experience of a crisis pregnancy in Ireland. Boylan (2019: 209) notes that:

Though these women were somewhat used to being in the public eye, revealing such private and painful experiences was remarkably generous; indeed, their high profiles left them exposed to receiving negative reactions, so their openness was particularly brave.

However, there is something problematic about requiring this performance of personal trauma in order to make or engage in social change. Smyth (1995: 35) argues that:

It is highly significant that it is invariably women who perform penance imposed through this process of public 'confession'. Women are the source of sin (and change), so women must be made to pay the sacrificial price.

As the referendum campaign gathered momentum, campaigners on both the Yes and No sides began messaging through imagery, posters, social media, leaflets, and video. Here, a familiar pattern began to emerge: the representation and impact of women's personal stories, heightened through their embodied images in addition to their narrative accounts. The Together for Yes campaign relied on the re-telling of women's personal stories and the foregrounding of medical evidence, specifically focused on the 'hard cases'. Contrastingly, the No campaign often removed the woman from the narrative altogether. Boylan (2019: 223) notes that:

A repugnant feature of the No campaign's often graphic posters had been the absence of women from them. They were merely silhouettes or headless torsos.

In short, both campaigns relied on the performative framing of narrative and imagery to produce significant affect throughout the public sphere to win the perceived middle-ground vote. Indeed, how significant is storytelling to Irish society?

\section{STORYTELLING: HUMANITY, IDENTITY, AND COMMUNITY}

'For what are we Maureen, if we're not our stories?' Dinny proclaims in Enda Walsh's darkly comic play The Walworth Farce (Walsh, 2006: 82). The setting is a dysfunctional Irish family living in London, isolated from communities, family and friends, exiled from their home in native Cork following a violent murder. They cannot process their trauma and so re-enact it daily as a method of survival, literal and autobiographical. Reiterating the horrific event again and again, the only logic or purpose these desperate characters can discern is the protection, validation, and reassurance of identity that occurs through the act of storytelling, even one as gruesome as theirs. On this power of storytelling, Irish philosopher Kearney (2002: 3) queries the fundamental connection between narrative and the condition of being human. In On Stories, he deftly surmises:

Telling stories is as basic to human beings as eating. More so, in fact, for while food makes us live, stories are what make our lives worth living. They are what make our condition buman.

These examples speak to the essential connection embedded in one's sense of self as producing meaning through the process of articulation. Indeed, this is what makes the landmark publication The Irish Journey: Women's Stories of Abortion so cutting. As the first account of Irish abortion testimonies that emerged as a collection, published as recently as 2000, it sought to fill this major gap in abortion literature. These testimonies are bitterly potent for so many women and families, not only because abortion is such a widespread experience, but because the experience of womanhood in Ireland is marked more by secrecy than anything else.

Pregnancy, abortion, miscarriage, infertility, IVF, surrogacy, sex, sexual desire, sexual abuse, sexual assault, shame, institutionalisation, medical scandals, cover-ups, denials, erasures, and absences; this is not the Irish theatrical or literary canon one usually encounters, but it is an account of widespread Irish experience and one that finds increasing space in Irish performance cultures. This historical secrecy is not necessarily imperceptible, however, as the markings of suppression and trauma leave a trace and these traces interweave to form a fabric. This fabric becomes a new model for community-formation; forged in difficulty, and often survived through exile or escape. These traumas mark the beginning of those stories, not the end. We are writing this article because of those stories and those communities, and our journeys are lighter because of the paths they trod. Womanhood in Ireland becomes constituted and reconstituted through the shared space of secrecy, the threat of shame, and the surprise of solidarity in one's darkest moments. This is the gentle shimmer of light that opens this unique collection The Irish Journey, where a woman, 'Jenny,' arrives home following an abortion in England and joins a women's support group. She needs to talk about her experience but cannot tell people due to the prevailing culture of fear, 
shame, and secrecy surrounding abortion. She goes to Easons (one of Ireland's largest chain of bookstores) to search for a book on it, displaying the innate human understanding that to identify one's story with someone else's story reasserts a sense of humanity and society. In Easons she looks for assistance and then:

three things struck her - that she couldn't ask for a book on abortion because then the assistant would know, that even if she found it she couldn't pay for it because the cashier would know, (to her own amazement Jenny contemplated stealing the book if she found it-but imagine being caught stealing a book on abortion, then everyone would know). The third thing that Jenny realised was that there was no book available at all (Ruane, 2000: 4).

The telling of this story in the women's support group led to much laughter. This group was a constituency of women marked by their secrecy. They became unified as a result of their isolating experiences, yet established their own community amidst a history and a present that has denied them healthcare, compassion and respect.

These women did not choose to keep their experiences of abortion secret without overwhelming cause. The consequences for engaging in pro-choice conversations throughout most of the twentieth century in Ireland were legally and socially severe; admitting to obtaining an abortion would likely unleash a wave of public and political anger. When Bacik was voted in as Students' Union President at Trinity College Dublin in 1989, the SU was already providing support services for women in need of abortion, though publications on abortion were censored at that time. She recounts that phone calls looking for assistance were daily and that the women were desperate (Bacik and Haughton, 2021). Bacik and her fellow officers received warning letters from the Society for the Protection of the Unborn Child (SPUC), and were then taken to court by the SPUC for providing information on abortion (Bacik, 2019). In addition, they received hate-mail and various threats, were spat at on the street, threatened with bankruptcy and could not mobilise wider support from sympathetic organisations or individuals, such as women's organisations or medics, as they too would face bankruptcy if associated with pro-choice support networks (Bacik and Haughton, 2021). Mary Robinson, the first female President of Ireland (1990-1997) and former UN High Commissioner for Human Rights (1997-2002) stepped in to represent the SU Officers as they approached their court date, warning them before trial to pack a bag as they would likely go to prison (Bacik and Haughton, 2021). In the end, they did not go to prison, but the personal and professional cost to them for providing information regarding how to access abortion services was extreme. The treatment of these students by the legal system, by the anti-abortion movement and by the public mood was well documented in the media of the time. It served to further the impact and affect of Ireland's punitive culture regarding abortion. If that can happen to the President of Trinity's SU for providing information, one might wonder: what would happen to me?

Bacik completed her undergraduate studies at Trinity and then relocated to the UK for postgraduate study, finding an active network of abortion support services for Irish women in London. Significantly, she also found a network of support to rebuild her confidence following the brutal and aggressive experience of pro-choice activism in Ireland. It is not surprising that so many Irish women looked to the UK not only for abortion services, but to become part of communities with less legal and moral policing on women's bodies and lives. Ann Rossiter's Ireland's Hidden Diaspora marks another watershed moment in Ireland's narrative journey of abortion. Many of these women came together under the banner of the Irish Women's Abortion Support Group (IWASG) and the Irish Abortion Solidarity Campaign (IASC), receiving some practical assistance from British health and welfare organisations, as well as support from the Spanish Women's Abortion Support Group (SWASG), based in London. Published in 2009, Rossiter (2009: 25) notes that 'this is the first time that many supporters and campaigners speak out without using pseudonyms'. The struggle for female bodily autonomy has confronted further challenges in Northern Ireland. While the Good Friday Agreement brought a significant period of peace to the male-dominated conflict known as 'The Troubles,' the peace agreement emerged partly from established political consensus to sacrifice women's autonomy. Goretti Horgan of Alliance for Choice in Northern Ireland summarises the cost of 'peace' for women:

In Northern Ireland we are now told that as a result of the Peace Agreement legal and political responsibility for abortion is to pass from Westminster to the Northern Irish parliament- the Assembly-whose seat is at Stormont. This means putting women's rights in the hands of the evangelical Taliban (Horgan in Rossiter, 2009: 20).

Following decades of pro and anti-abortion campaigning, abortion in Northern Ireland was decriminalised in 2019, with a new framework for lawful abortion services coming into effect in 2020 as a result of intervention by the British government (Amnesty UK, 2021; McCormack, 2021). However, these services have experienced ongoing political challenges and disruption since their implemention (McCormack, 2021). In July 2021, Westminster took the unprecedented step of directing Stormont's Department of Health to set up full abortion services in Northern Ireland by no later than March 2022 (McCormack, 2021). 


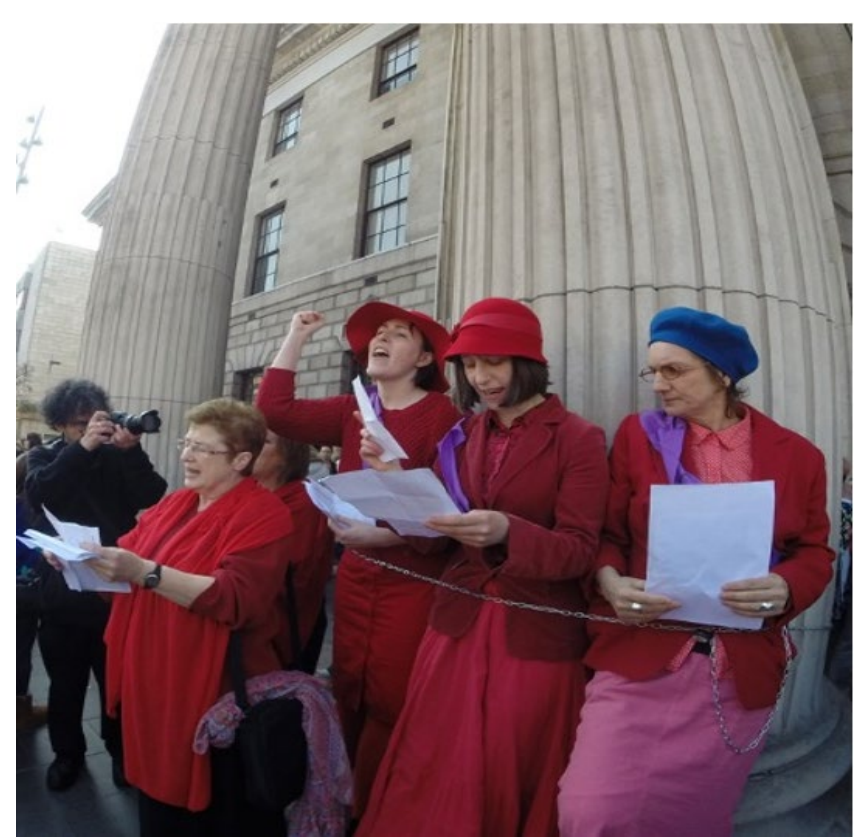

Figure 1. Speaking of IMELDA performance at GPO, Dublin. Photograph by Georgina Willis. Used with permission

The obsessive focus on women's bodies by hegemonic forces suppressed women's autonomy in everyday contexts, but also nurtured solidarity in many other ways. Rossiter's (2009) arresting study maps the creative and vital ways women mobilised to support each other as they made plans to travel to the UK for abortions: the booking of tickets, meeting someone at an airport or ferry, navigating the underground rail system in London, finding the clinic, offering accommodation, and, of priceless value, providing understanding, company and compassion. We may never know all the names of these groundbreaking women as they will continue to protect promises of privacy, but we can appreciate and celebrate their immense contribution to Irish women's lives as new research on abortion emerges in more open cultural climates. Some of these histories are captured by the Londonbased direct-action feminist group 'Speaking of IMELDA,'8 standing for 'Ireland Making England the Legal Destination for Abortion', as well as referencing the use of 'Imelda' as a code word for abortion used by IWASG. They pay homage to the work of IWASG through their own name, as well as wearing red costumes during their performances, as IWASG members often wore red to be identifiable to Irish women travelling to the UK.

The group's performances directly and explicitly confront notions of respectability circulated throughout twentieth-century Ireland. Performances include 'knicker-bombing' former Taoiseach Enda Kenny while he attended a fundraising dinner in London in 2014, chaining themselves to Dublin's iconic General Post Office building during the state-broadcast 'Road to the Rising' centenary commemoration in 2015 (Figure 1), and visiting England's Secretary of State for Health, Jeremy Hunt, in a Sainsbury's supermarket in Surrey during his 'Advice Surgery' for constituents in 2014. The IMELDA's performances have occurred throughout Ireland, Northern Ireland and Britain, extend to public talks and keynote lectures, and academic publications. From their emergence in 2013, they have ensured that Irish women's rights to abortion, bodily autonomy, healthcare, and compassion have been centralised in moments of major global attention on Irish politics, such as St Patrick's Day Parades and 1916 Centenary events. They confronted politicians directly, as well as engaging the wider public with their humorous yet politically-pointed performances. They represent the continued development of Irish women's solidarity in the UK, refusing to tolerate antiquated laws that infringe on human rights. They took public space as their stage, and Ireland as their story. Finally, they can 'hang their knickers up' (Walsh, 2020).

\section{WOMEN'S PLACE, WOMEN'S MOBILITY: THE RISE OF REVERSE MIGRATION AND SOCIAL MEDIA}

It is estimated that more than 170,000 women and pregnant people made the journey between Ireland and Britain since 1970, with an additional 1,000 per year ordering abortion pills and a few choosing other states in which to receive services (Bardon, 2018; Sheldon, 2016: 90-101). Even when seeking abortion abroad was decriminalised, the myth of an abortion-free Ireland required secrecy and silence from women and pregnant people

${ }^{8}$ For a comprehensive account of the group's history and activities, see https:/ / www.speakingofimelda.org (Accessed 7 April 2020). 
who required such health care. Journeys for abortion to the UK and further afield, with their attendant stigma and secrecy, constitute an onerous, painful physical and affective separation from support networks and social circles. They also demonstrate the intertwined affective and political impact of the respectability and responsibility narratives and the reality of Dowler and Sharp's (2001: 168) statement:

Women's bodies are inherently caught up in international relations, but often at mundane or everyday levels and so are not written into the texts of political discourse. However, as Enloe $(1989,1993)$ has long insisted, this does not mean that women have no role in the recreation of international orders, simply that their agency is hidden from the traditional gaze of geopolitics.

With the advent of social media, the loneliness and shame many women experienced while seeking abortion abroad was rendered visible to previously private support networks and social circles. The 'hidden agency' of Irish emigrants for reproductive choice and their allies became very visible in the campaign to repeal the 8th Amendment when the hashtag \#HomeToVote demonstrated their intent to travel back to Ireland, sometimes at great cost, in order to cast their ballots ${ }^{9}$. The staging and symbols of these images constitute a demand for visibility and participation in political power from those seeking reproductive choice, made with the help of a widespread network of emotional and political supporters.

Staged marches around the world, publicised through Twitter, Instagram, and Facebook, featured women pulling suitcases through city centres and past governmental buildings, thus re-performing these journeys as a claiming of the public eye and public space (Flynn, 2015; Russell, 2014). Marchers moved silently in single file or in lines of two, creating images that represent the duration and loneliness of travel and the repetition of the journey by so many. One such photo by Alastair Moore became a key representation of travel, reproduced in many articles and social media posts. The image of silent women walking with suitcases through public spaces articulates the desire to be seen as a whole woman, including one's choice to have an abortion, and the silencing and distancing enacted by society on those who make that desire known. Many social media posts replicating the image included no text or only a few words, using this image to declare their support for the marchers or announcing their inclusion into the ranks of women represented. Reposts of the image with comments such as 'this was me' and 'I took the boat' borrowed the affective power of the image to declare the complexity of their own identities. Until the time of writing the image also remains the focal point of the London-Irish ARC webpage at LondonIrishARC.com, signifying the group's commitment to be a voice for the silent travellers (Zatat, 2018). Similarly, the emotional accounts of abortion experiences shared anonymously through the Facebook page InHerShoes, curated by Erin Darcy, were often accompanied by images of shoes that created a narrative of travel while emphasising the risks of visibility for the storyteller (Barr, 2019). Such images and narratives expanding virally through online networks became central to the pro-choice campaign, again emphasising the importance of affective messaging in developing a community through which to claim membership in the larger political entity.

In Elspeth Probyn's Writing Shame she calls shame 'an exposure of the intimacies of selves in public' in a phrase that resonates strongly with the layers of shame around travel to procure an abortion (Probyn, 2009: 72). First, pregnancy itself is the result of an intimate encounter. Second, the need to end a pregnancy is portrayed as the failure of a woman's responsibility. Third, each entry into public spaces such as ferries and airports on the journey risks exposure of these intimacies, subjecting one's private life to the judgement of others. Thus, the politics of affect and affective response are key to the analysis of images on social media, as the spread of such images once published is not in the control of the subject. Images that do include a person, such as the suitcase marchers, represent and perform the figure forced by law to travel without requiring the subject claim the experience herself. Such images begin to establish a 'beachhead,' as Tomkins (1995: 175) puts it, against the sticky affect of shame by reminding viewers that the embodied experience behind the image is complex and human.

Images posted with the hashtag \#HomeToVote, such as this photograph by Kehoe (2018), represent an extension of this beachhead by performing a reversed arc of travel both affectively and physically to that of the emigrant (Figure 2). In such images the travel represented is a performance of citizenship and a claim to political power. Shared, it is also a collective performance that establishes a social circle and community, deliberately reversing the isolating impact of shame. On 8 February 2018 the London-Irish ARC (Abortion Rights Campaign) published an online appeal to 'the Irish abroad' to post images of themselves, the areas in which they reside and their passports, and to signal their journey using the hashtag ${ }^{10}$. Along with the blog post they published the website

\footnotetext{
${ }^{9}$ Under Section 11(3) of the Electoral Act 1992, Irish citizens abroad retain full voting rights for only eighteen months and only if they intend to return to Ireland (Dáil Éireann, 1992). Many supporters of the Repeal campaign whose voting rights had expired used an associated hashtag to offer emotional and financial support to those who could legally return home to vote: \#BeMyYes, discussed later in this article ('Women Unable to Vote...', 2018).

10 '\#HOMETOVOTE: A REFERENDUM IS ON THE WAY AND IRELAND NEEDS YOU'. 2018. Blog. London Irish ARC. 8 February 2018.
}

$10 / 16$

(C) 2022 by Author/s 


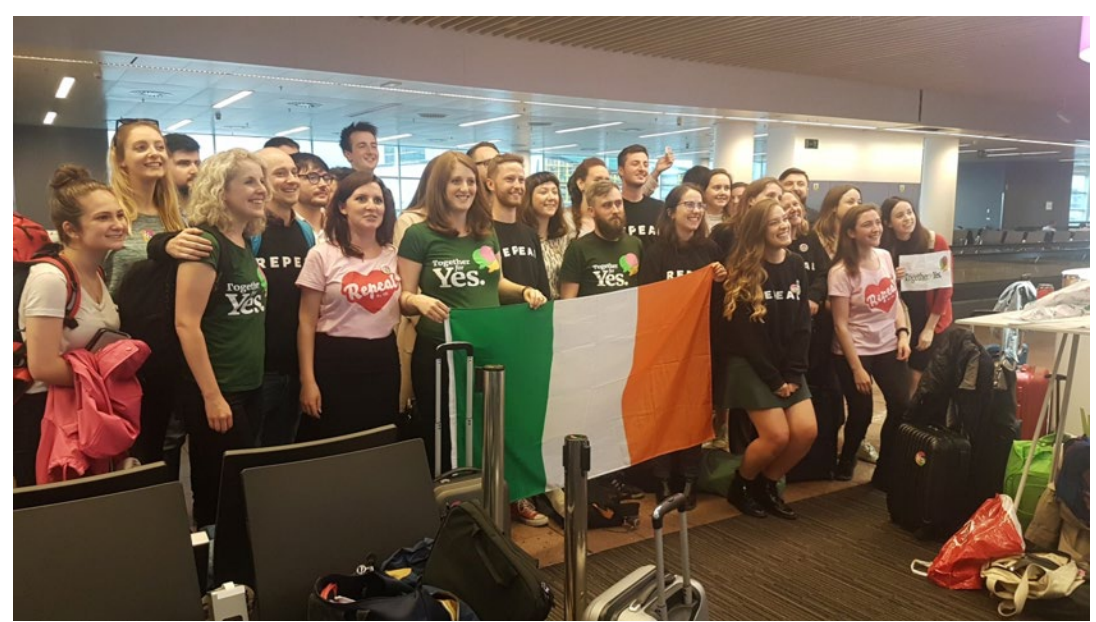

Figure 2. People waiting to board a flight from Brussels to Dublin in order to vote. Photograph by Paula Kehoe. Used with permission

hometovote.com which features a video representing multiple stories of travel to Ireland demonstrating distance through iconic skylines, effort through clips of weary travellers in empty airport lounges, and community through the welcoming hugs of other Repeal voters (London-Irish ARC, 2018).

Similarly, Kehoe's (2018) photo taken of the pro-choice passengers on a single flight from Brussels to Dublin demonstrates the creation of a new social group and identity based on activism as a performance of patriotism. The physical proximity of the group, along with their smiles and expressions of pride, indicate membership in this community, as do the multiple 'Repeal' and 'Together for Yes' jumpers, shirts and badges: the pro-choice costume. The pile of baggage abandoned for the photograph indicates a level of trust in this community. The prominent inclusion of the Irish flag is a demonstration of inclusion in the civic body of Ireland as a collective activist body with political power rather than silenced, separated, shameful bodies.

To analyse the images of \#HomeToVoters as the performance of citizenship is to participate in the ongoing reconfiguration of citizenship beyond the physical boundaries of the state. Legal scholar Barry (2006: 11-59) uses the term 'external citizenship' to describe this reconfiguration and examines the decoupling of residence and citizenship in both legal and experiential terms. Barry (2006: 18) notes that:

Citizenship, so long a symbol of rootedness, exclusivity and permanence—has been discovered to be portable, exchangeable, and increasingly multiple.

Barry (2006) supports Linda Bosniak's argument that the legal status 'citizenship' is only one dimension of the concept, with rights, political activity and 'a form of collective identity and sentiment' being equally as important (Bosniak in Barry, 2006: 20) ${ }^{11}$. The 'practiced identity' of the external citizen anchors their understanding of themselves as 'part of a larger group defined by a shared history, genealogy, territory, or political-ideological vision' (2006: 23). This practice is the participation of the emigrant in civil society not simply by voting but by developing and maintaining personal bonds and networks of relationship that constitute a community.

The affective content of such images can assist in building this community of support. Social communication theorists Kivran-Swaine and Naaman (2011: 382) find a positive relationship between expression of emotion in posts and the number of followers a Twitter user has, arguing that 'the shared emotional experiences create more engaging content'. They also note that it can be costly to share emotional experiences in such a semi-public forum, and so the affective content may be more highly valued as a 'gift' to one's followers. The direct exchange of these 'gifts' further cements a network and support system and makes it more likely that action in the non-digital world will follow. The development of these networks supports users' demand to be recognised and included as part of a community, and therefore the use of social media to display journeys to vote can be read as a demand for active membership in the community of Irish citizens, a demand to be seen and heard.

While it is impossible to verify that those who used the \#HomeToVote hashtag actually voted, the Irish Abroad Unit estimates the number of Irish citizens' resident outside the state at 3.601 million (Department of Foreign Affairs and Trade, Ireland, 2017: 6). The London Irish ARC estimates based on data from the Central Statistics Office that more than 40,000 emigrants were eligible to vote in the 2018 referendum (Kenny, 2018). Though media reports included examples of \#HomeToVoters announcing their intention to vote 'No', a review of the hashtag

11 These categorisations reflect the contested nature of the term 'citizenship'. For more, see Bosniak's (2000) survey of citizenship discourses in Citizenship Denationalized (The State of Citizenship Symposium), Indiana Journal of Global Legal Studies, 7(2): 447-509. 


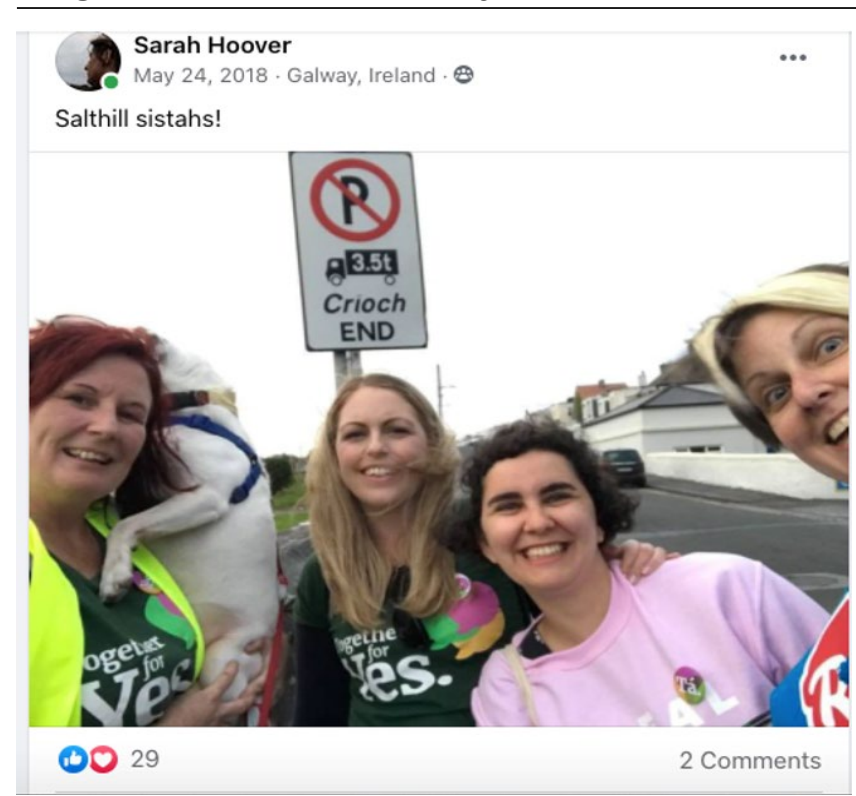

Figure 3. Facebook post featuring Together for Yes campaigners and \#BeMyYes. Image by Sarah Hoover. Used with permission

trends between February and May of 2018 shows a sizable majority of \#HomeToVote posts also include the hashtag \#Repealthe8th, \#Together4Yes, or similar 'Yes' slogans ${ }^{12}$. This public performance establishes the \#HomeToVoters as within the social circles and communities of Ireland and represents a performance of citizenship that incorporates the affective and performative roles of social media in the development of such communities.

Leaving aside its influence in increasing the percentage of eligible voters that use their vote, however, the \#HomeToVote hashtag revealed the ways that Irish pro-choice supporters were publicly performing their Irish identity by claiming their right to influence the referendum. Due to the durational restriction on voting rights the \#HomeToVoters are often students, interns, and those spending time abroad as a cultural exploration. However, many emigrants leave Ireland to take advantage of economic opportunities or to further other relationships, potentially unsure as to whether they will return though still retaining strong ties with their resident community in Ireland. Others are affected by legislation in the Republic of Ireland, such as those who live in the North or people who are ordinarily resident or seeking asylum. For them, \#BeMyYes gave an opportunity to simultaneously support better access to abortion and highlight the divisions between those with political power and those without.

As Honohan (2011: 557) notes, a strong argument for Irish emigrant voting rights 'rests on the fact that most emigrants leave out of economic need rather than freely chosen career opportunities or other goals' and refusing their voting rights adds insult to injury. For Honohan (2011: 558), the high rates at which emigrants return to Ireland after years of retaining ties there does 'provide evidence of a genuine connection among a significant proportion of emigrants'. This connection is anecdotally evidenced by the numbers of emigrants who, not eligible to vote themselves, provided financial and logistical support to \#HomeToVoters. The twitter account @abroadforyes and related Facebook group Abroad for Yes established themselves as linking agencies between these supporters and those in need of assistance with tickets, accommodation, and travel from the airport to a voting station. The Facebook group alone had significant impact, garnering over six thousand members. \#BeMyYes became a means by which those who could not vote in the referendum still influenced its outcome by emphasising their dependence on those who could (Baker and Belam, 2018). Though many people posted their individual pleas for a 'Yes' vote, \#BeMyYes events that culminated in photos (Figure 3) were held around the world so that group images of attendees, Irish flags, signs with hashtags and other messages could be spread through social media ('Women Unable to Vote ...', 2018).

\footnotetext{
${ }^{12}$ A few examples include BBC News, The people travelling \#HomeToVote, 26 May 2018, https://www.bbc.com/news/ world-europe-44223949; Independent.ie, 'I would walk home from Timbuktu to vote', 21 May 2018, https:/ / www.independent.ie/irish-news/abortion-referendum/i-would-walk-home-from-timbuktu-to-vote-meet-the-youngpeople-who-are-travelling-hometovote-36920920.html; Irish Times Coming \#HomeToVote, 24 May 2018 , https:/ / www.irishtimes.com/life-and-style/abroad/coming-hometovote-top-tweets-from-emigrants-making-epic-journeysback-1.3507119; ABC.net.au, Abortion referendum: \#hometovote movement brings thousands back to Ireland, 25 May 2018 , https://www.abc.net.au/news/2018-05-26/abortion-vote-home-to-vote-brings-thousands-back-to-ireland/9803068; and NPR's All Things Considered, Thousands of Irish expats return home to vote in abortion referendum, 25 May 2018 (transcript at https:/ /www.npr.org/2018/05/25/614518518/thousands-of-irish-expats-return-home-to-vote-in-abortion-referendum).
} 


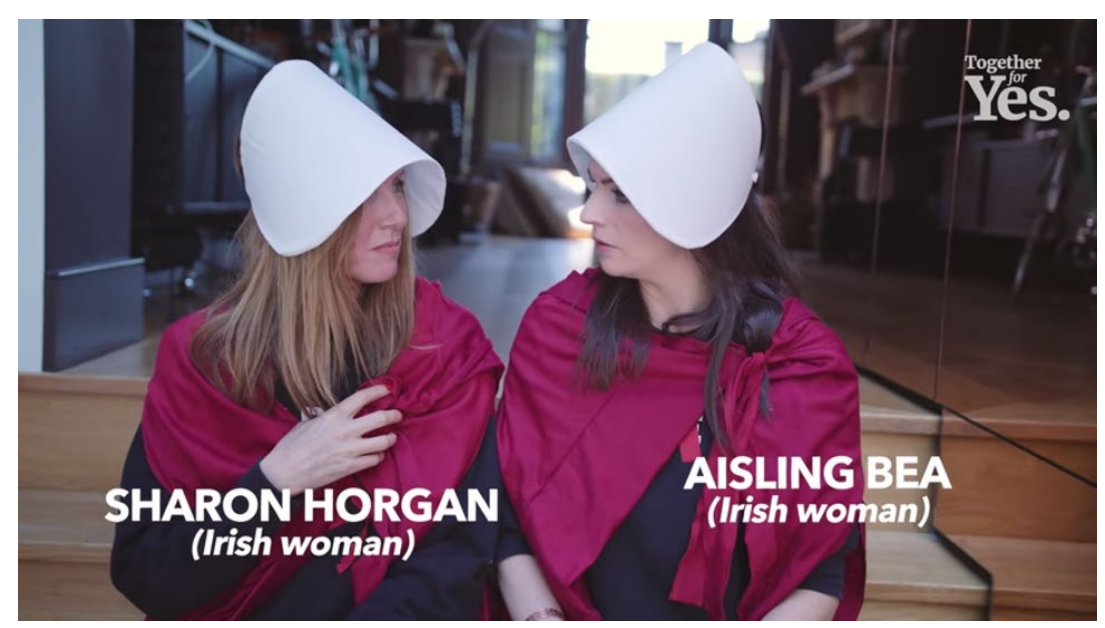

Figure 4. Screenshot of YouTube video 'Irish Comedians Abroad: Be Our Yes'. Posted by Andrew Nolan, public access

Posts under the \#BeMyYes umbrella often visually reference the marches, protests and other gatherings in a demonstration of solidarity, inclusion in a social circle through shared social values, and a stake in the larger community of Irish citizenship. The post above, made by one of this article's authors, references her relationship to the community as a means of claiming the right to influence laws that govern that community. This post is tagged with \#BeMyYes in the comments. Similarly, other posts come from those who have lost the legal right to influence laws governing a community in which they still play a part. Comedians Aisling Bea and Sharon Hogan (Figure 4) released a video on YouTube with themselves and others calling for a 'Yes' vote using the hashtag \#BeMyYes (Irish Comedians Abroad: Be Our Yes, 2018). It is telling that a section of the video satirises the narrative that accuses emigrants of abandoning their society. Bea announces, 'We are the Judases who left Ireland and can no longer vote.' Gránne Maguire declares 'I sold out my country for the queen's shilling,' before Bea takes a more serious tone to remind viewers: 'We no longer have a voice in our own beloved country' (Irish Comedians Abroad: Be Our Yes, 2018: 1:56-2:06). This video satirically challenges the definition of the respectable Irish woman, the Irish woman with a right to intervene in Irish policy and law, as one who does not leave Ireland.

\section{CONCLUSION}

This article finds that the problematic relationship between nation and female bodily autonomy in Ireland is weakening, but not yet undone. The idealised, respectable Irish woman—often presented publically as white, middle-class, married, Anglophone, and heterosexual- has borne the responsibility for the moral construction of the Irish society and nation in her body for generations, according to value-systems which are discriminatory at best, and often violent in their full impact and consequence. This performance of Irish woman-ness in both public and private spheres was visibly challenged during the Referendum campaign, though the homogeneity of these challenges demonstrates that the narratives of respectability remain influential. They place significant pressure on women and pregnant people in Ireland to maintain a specific image in order to remain a vital part of the community. However, the complexity of Irish women's experiences escapes these definitions and find creative ways to resist these pressures; by boldly claiming the public eye and the public space, such as with Speaking of IMELDA, and by repeating and retaining the symbols of Irishness and Irish citizenship through localised and online performances made collective through hashtags such as \#HomeToVote and \#BeMyYes. This article argues that the widening window of visibility available for Irish woman-ness requires continued attention in order to incorporate the experiences and bodies that actually constitute Irish society, and that increasing the awareness of such projects is an opportunity provided by the Referendum and continuing today.

\section{REFERENCES}

Ahmed, S. (2004). The cultural politics of emotion. Edinburgh: Edinburgh University Press.

Ahmed, S. (2005). The skin of the community: Affect and boundary formation, in T. Chanter and E. Płonowska Ziarek (eds), Revolt, affect, collectivity: The unstable boundaries of Kristeva's polis (pp. 95-112). Albany: State University of New York Press.

Ahmed, S. (2010). Happy objects, in M. Gregg and G. J. Seigworth (eds), The affect theory reader (pp. 29-51). Durham, NC: Duke University Press. https://doi.org/10.1215/9780822393047-001 
Ahmed, S. (2017). Living a feminist life. Durham, NC: Duke University Press. https://doi.org/10.1215/ 9780822373377

Amnesty UK. (2020). Abortion decriminalised in Northern Ireland. 31 March 2020. Amnesty.org. Available at: https://www.amnesty.org.uk/abortion-rights-northern-ireland-timeline (Accessed 25 November 2021).

Archer Mann, S. and Huffman, D. J. (2005). The decentering of second wave feminism and the rise of the third wave. Science and Society, 69(1), 56-91. https://doi.org/10.1521/siso.69.1.56.56799

Bacik, I. (2019). Ivana's story-Abortion and the referendum in Ireland. International Planned Parenthood Federation. 15 January 2019. Available at: https://www.ippf.org/ivanas-story-abortion-and-referendum-ireland (Accessed 25 November 2021).

Bacik, I. (2021). Unpublished interview with Miriam Hanghton. 23 March 2021.

Baker, S. and Belam, M. (2018). Irish pro-choice campaigners recount \#HomeToVote journeys online. The Guardian, 25 May 2018. Available at: https://www.theguardian.com/world/2018/may/24/irish-abortioncampaigners-recount-hometovote-journeys-online (Accessed 25 November 2021).

Bardon, S. (2018). Fact check: Have more than 170,000 Irish women travelled abroad for an abortion? The Irish Times, 2 May 2018. Available at: https://www.irishtimes.com/news/politics/fact-check-have-more-than-170000-irish-women-travelled-abroad-for-an-abortion-1.3481581 (Accessed 25 November 2021).

Barr, R. A. (2019). Repealing the Eighth: Abortion referendum was won by narrative. The Irish Times, 31 May 2019. Available at: https://www.irishtimes.com/culture/books/repealing-the-eighth-abortion-referendum-waswon-by-narrative-1.3909909 (Accessed 25 November 2021).

Barry, K. (2006). Home and away: The construction of citizenship in an emigration context. New York University Law Review (Symposium: A Tribute to the Work of Kim Barry: The Construction of Citizenship in an Emigration Context: Introduction), 81(1), 11-59.

Begas, A. (2016). Trust women-Repeal the 8th (Video). Available at: https://wellwomancentre.ie/trust-women-repeal8th-video/ (Accessed 25 November 2021).

Boylan, P. (2019). In the shadow of the eighth: My forty years working for women's health in Ireland. Dublin: Penguin Ireland.

Browne, K. and Nash, C. J. (2020). In Ireland we 'love both'? Heteroactivism in Ireland's anti-Repeal Ephemera. Feminist Review, 124, 51-67. https:// doi.org/10.1177/01417778919895262

Buckley, S. A., Cunningham, J., Haughton, M. and Houlihan, B. (2021). To talk, to tell, to share: The Tuam Oral History Project. Catedra de Estudos Irlandeses, 91-124.

Candon, N. (2020). The election's unspoken issue. Village. 2 July 2020. Available at: https:/ villagemagazine.ie/theelections-unspoken-issue/ (Accessed 25 November 2021).

Carbin, M. and Edenheim, S. (2013). The intersectional turn in feminist theory: A dream of a common language? European Journal of Women's Studies, 20(3), 233-248. https://doi.org/10.1177/1350506813484723

Carnegie, A. and Roth, A. (2019). From the grassroots to the Oireachtas: Abortion law reform in the Republic of Ireland, Health and Human Rights, 21(2), 109-120.

Chakravarty, D., Feldman, A. and Penney, E. (2020). Analysing contemporary women's movements for bodily autonomy, pluriversalizing the feminist scholarship on the politics of respectability. Journal of International Women's Studies, 21(7), 169-188.

Connolly, L. (2003). The Irish women's movement: From revolution to devolution. London and New York: Macmillan/Palgrave.

Connolly, L. (ed). (2015). The 'Irish' family. Milton Park: Routledge. https://doi.org/10.4324/9780203736760

Connolly, L. and O’Toole, T. (2005). Documenting Irish feminisms: The second wave. Dublin: Woodfield.

Cullen, P. and Korolczuk, E. (2019). Challenging abortion stigma: Framing abortion in Ireland and Poland. Sexual and Reproductive Health Matters, 27(3), 6-19. https://doi.org/10.1080/26410397.2019.1686197

Dáil Éireann. (1992). Electoral Act, 1992. Available at: http://www.irishstatutebook.ie/eli/1992/act/23/ enacted/en/html (Accessed 25 November 2021).

Department of Foreign Affairs and Trade, Ireland. (2017). Irish Emigration Patterns and Citizens Abroad. An Roinn Gnóthaí Eachtracha agus Trádála-Department of Foreign Affairs and Trade, Ireland. Available at: https://www.dfa.ie/media/dfa/alldfawebsitemedia/newspress/publications/ministersbrief-june2017/1-Global-Irish-in-Numbers.pdf (Accessed 25 November 2021).

Dowler, L. and Sharp, J. (2001). A feminist geopolitics? Space and Polity, 5(3), 165-176. https://doi.org/10.1080/ 13562570120104382

Ferriter, D. (2010). Occasions of sin: Sex and society in modern Ireland. London: Profile Books.

Fischer, C. (2016). Gender, nation, and the politics of shame: Magdalen Laundries and the institutionalisation of feminine transgression in modern Ireland. Signs: Journal of Women in Culture and Society, 41(4), 821-843. https://doi.org/10.1086/685117

Fischer, C. (2017). Revealing Ireland's 'proper' heart: Apology, shame, nation. Hypatia: A Journal of Feminist Philosophy, 32(4), 751-767. https://doi.org/10.1111/hypa.12358 
Fischer, C. (2019). Abortion and reproduction in Ireland: Shame, nation-building, and the affective politics of place. Feminist Review, 122(2), 32-48. https://doi.org/10.1177/0141778919850003

Fischer, C. (2020). Feminists redrawing public and private spheres: Abortion, vulnerability, and the affective campaign to repeal the Eighth Amendment.Signs, 45(4), 985-1010. https://doi.org/10.1086/707999

Flynn, T. (2015). Tara Flynn: You don't talk about abortion in Ireland. But I have to. The Irish Times, 14 September 2015. Available at: https://www.irishtimes.com/life-and-style/people/tara-flynn-you-don-t-talk-aboutabortion-in-ireland-but-i-have-to-1.2344617 (Accessed 25 November 2021).

Grosz, E. A. (2004). The nick of time: Politics, evolution, and the untimely. Durham: Duke University Press. https://doi.org/10.2307/j.ctv1134f5v

Hill, S. (2019). Women and embodied mythmaking in Irish theatre. Cambridge: Cambridge University Press. https://doi.org/10.1017/9781108756327

Hogan, C. (2019). Republic of shame. London. Penguin Books.

Honohan, I. (2011). Should Irish emigrants have votes? External voting in Ireland. Irish Political Studies, 26(4), 545561. https://doi.org/10.1080/07907184.2011.619749

HuffPost UK. (2018). Women unable to vote in Irish abortion referendum urge others to \#BeMyYes. Huffington Post UK, 23 May 2018. Available at: https://www.huffingtonpost.co.uk/entry/irish-abortion-referendumbemyyes_uk_5b0547d9e4b07c4ea1038d7f (Accessed 25 November 2021).

Irish Comedians Abroad: Be Our Yes. (2018). Available at: https://www.youtube.com/ watch? $\mathrm{v}=\mathrm{XAGmrgTWUTw \& feature=youtu.be}$ (Accessed 25 November 2021).

Kearney, R. (2002). On stories. Thinking in action. London \& New York: Routledge. https://doi.org/10.4324/ 9780203453483

Kehoe, P. (2018). @PaulaMKehoe. Brussels Airport boarding to Dublin: The passengers on one flight \#hometovote \#Repealthe8th. Twitter, 5 May 2018. Available at: https://twitter.com/TwitterDublin/ status/ 601821365335957504 (Accessed 25 November 2021).

Kenny, C. (2018). Illegal emigrant voting: How \#HometoVote could backfire. The Irish Times, 10 February 2018. Available at: https://www.irishtimes.com/life-and-style/abroad/illegal-emigrant-voting-how-hometovotecould-backfire-1.3385321 (Accessed 25 November 2021).

Kivran-Swaine, F. and Naaman, M. (2011). Network properties and social sharing of emotions in social awareness streams, in Proceedings of the ACM 2011 Conference on Computer Supported Cooperative Work-CSCW 11: 379-382. Hangzhou, China: ACM Press. https://doi.org/10.1145/1958824.1958882

London Irish ARC. (2018). \#HOMETOVOTE: A REFERENDUM IS ON THE WAY AND IRELAND NEEDS YOU. Blog, 8 February. No longer accessible.

London-Irish ARC. (2018). \#HomeToVote|Vote Yes to remove the 8th Amendment on May 25th. YouTube, 23 April 2018. Available at: https://www.youtube.com/watch?v=cw_ylrOL_70 (Accessed 25 November 2021).

McCormack, J. (2021). Abortion in NI: Westminster directs stormont to set up services. BBC News, 23 July 2021. Available at: https://www.bbc.com/news/uk-northern-ireland-57921537 (Accessed 25 November 2021).

Murray, E. and Grimes, L. (2021). Trauma of women compelled to give up their babies for adoption laid bare in Irish academic's research. Independent, 14 January 2021. Available at: https://www.independent.ie/irishnews/trauma-of-women-compelled-to-give-up-their-babies-for-adoption-laid-bare-in-irish-academicsresearch-39966620.html (Accessed 25 November 2021).

Opie, I. and Tatem, M. (eds). (1996). A dictionary of superstitions. Oxford, UK: Oxford University Press. https://doi.org/10.1093/acref/9780192829160.001.0001

Pedwell, C. and Whitehead, A. (2012). Affecting feminism: Questions of feeling in feminist theory. Feminist Theory, 13(2), 115-129. https://doi.org/10.1177/1464700112442635

Probyn, E. (2009). Writing shame, in M. Gregg and G. J. Seigworth (eds), The affect theory reader (pp. 71-92). Durham, NC: Duke University Press. https://doi.org/10.1215/9780822393047-003

Rosenfelt, D. and Stacey, J. (1987). Second thoughts on the second wave., Feminist Review, 27, 77. https://doi.org/10.2307/1394812

Rossiter, A. (2009). Ireland's bidden diaspora the 'abortion trail' and the making of a London-Irish underground, 1980-2000. London: IASC.

Ruane, M. (2000). Introduction, in The Irish journey: Women's stories of abortion (pp. 6-11). Dublin: Irish Family Planning Association.

Russell, C. (2014). Most voters want a referendum to decide if Ireland's abortion laws should be liberalised. The Journal, 13 October 2014. Available at: https://www.thejournal.ie/referendum-abortion-laws-1720446Oct2014/ (Accessed 25 November 2021).

Sedgwick, E. K. (2003). Touching feeling: Affect, pedagogy, performativity. Durham: Duke University Press. https://doi.org/10.2307/j.ctv11smq37.7 
Sheldon, S. (2016). How can a state control swallowing? The home use of abortion pills in Ireland. Reproductive Health Matters, 24(48), 90-101. https://doi.org/10.1016/j.rhm.2016.10.002

Sihra, M. (2007). The house of woman and the plays of Marina Carr, in M. Sihra (ed), Women in Irish drama: A century of authorship and representation (pp. 201-218). London: Palgrave Macmillan UK. https://doi.org/10.1057/ 9780230801455_13

Smith, J. (2008). Ireland's magdalen laundries and the nation's architecture of containment. Manchester: Manchester UP. https://doi.org/10.2307/j.ctvpj76pf

Smyth, A. (1995). States of change: Reflections on Ireland in several uncertain parts. Feminist Review, 50(1), 24-43. https://doi.org/10.1057/fr.1995.20

Specia, M. (2018). How Savita Halappanavar's death spurred Ireland's abortion rights campaign. The New York Times, 27 May 2018. Available at: https:/ /www.nytimes.com/2018/05/27/world/europe/savita-halappanavarireland-abortion.html (Accessed 25 November 2021).

Tomkins, S. (1962, republished 2008). Affect, imagery, consciousness: The complete edition. Vol. I and II. New York: Springer.

Tomkins, S. (1995). Shame-humiliation and contempt-disgust, in E. K. Sedgwick, A. Frank and I. E. Alexander (eds), Shame and its sisters: A Silvan Tomkins reader (pp.133-178). Durham: Duke University Press.

Tuam Oral History Project, NUI Galway. (2019-2023). NUI Galway. Available at: https:/ /www.nuigalway.ie/tuamoral-history/ (Accessed 25 November 2021).

Walsh, H. (2020). Hanging our knickers up: Asserting autonomy and cross-border solidarity in the \#RepealThe8th campaign. Feminist Review, 124(1), 144-151. https:/ / doi.org/10.1177/0141778919894950

Zatat, N. (2018). Photographer explains how he captured viral photo that came to symbolise the Irish Abortion Referendum. Indy100, 28 May 2018. Available at: https://www.indy100.com/article/photographer-explainsphoto-came-to-symbolise-irish-abortion-referendum-viral-8372406 (Accessed 25 November 2021).

Citation: Haughton, M., Hoover, S. and Murphy, C. L. (2022). Think Outside My Box: Staging Respectability and Responsibility in Ireland's Repeal the 8th Referendum. Feminist Encounters: A Journal of Critical Studies in Culture and Politics, 6(1), 11. https://doi.org/10.20897/femenc/11755

Copyright (C) 2022 by Author/s and Licensed by Lectito BV, Netherlands. This is an open access article distributed under the Creative Commons Attribution License which permits unrestricted use, distribution, and reproduction in any medium, provided the original work is properly cited. 